\title{
Hepatitis C Virus Core Antigen Measurement
}

National Cancer Institute

\section{Source}

National Cancer Institute. Hepatitis C Virus Core Antigen Measurement. NCI Thesaurus. Code C135424.

The determination of the amount of hepatitis C virus core antigen in a biological sample. 